\begin{tabular}{|c|cc|}
\hline & PORT-SAID ENGINEERING RESEARCH JOURNAL \\
\hline
\end{tabular}

\title{
Analysis of Pounding between Two Adjacent Buildings during an Earthquake
}

\author{
Mohamed Adel ${ }^{1}$, Ashraf Elsabbagh ${ }^{2}$, and Mohamed Elghandour ${ }^{3}$
}

\begin{abstract}
The aim of this paper is to study the effect of collisions between the adjacent structures during the earthquake and its effect on the behavior of the structure. The collisions could lead to local damage or even total collapse of colliding structures. A model was performed on the ETABS program to model the pounding between the adjacent structures by using Gap element. The study was applied on a different height and a gap distance between the adjacent structures in order to understand and explain the effect of collision on the behavior of the structure and to clarify the danger of its occurrence. The results of the studied cases in case of pounding were compared with the normal case without pounding, where the Displacement, inter storey drift, impact force and max storey shear force were discussed. These results showed that both buildings were affected by the collision. Therefore, precautions should be taken to prevent the collision by having sufficient distance or design a system that can withstand the force resulting from these shocks.
\end{abstract}

KEYWORDS: Pounding - adjacent buildings - ETABS - Nonlinear analysis - impact force - gap distance.

\section{INTRODUCTION}

\subsection{Background Review}

During the earthquake there are many types of failures and damage that may occur to the building. Some are due to design errors and others are due to external factors that have not be taken into account in design such as, pounding between adjacent structures.

One of the most serious factors affecting the building during the earthquake is the collision between the adjacent structures. Lack of sufficient distance cannot provide a space for the response of the structure as different dynamic characteristics of adjacent structure. Usually, risk of pounding is because of resulting in impact force on the building was not taking into account, occurred when designing the structure which can lead to a total collapse of the structure.

Pounding between adjacent buildings has been observed during many historical earthquakes where it is one of the reasons that led to significant damage to buildings such as the 2010 Darfield earthquake (1), the 1989 Loma Prieta earthquake (2) and The Mexico Earthquake-1985 (3).
The damage resulting from the pounding between the adjacent structures can be divided into two types: Type one is local damage caused by point of impact, type two is global damage depends on the dynamic characteristics of adjacent structure.

\subsection{Research objectives}

1- Select of the most important and most common variables to study their effects on the pounding phenomenon, such as the building height, the separation distance, the earthquake record and building arrangement.

2- Suggest a model which is able to simulate the behavior of the structure during the pounding and is able to represent the impact force between the adjacent structures correctly.

3- Negative or positive effects have been determined by comparing the results of the structure in the case of pounding with the normal case without pounding.

4- Introduce recommendations and conclusions.

\footnotetext{
${ }^{1}$ Master Student,Faculty of Engineering, Civil Engineering Department, Port Said University, Email: Mohamed.adelll|3333@gmail.com

${ }^{2}$ Assistant Professor, Faculty of Engineering, Civil Engineering Department, Port Said University, Email: ashraf_ims@yahoo.com

${ }^{3}$ Professor, Faculty of Engineering, Civil Engineering Department, Port Said University, E-mail: dr.elghandor@gmail.com https://dx.doi.org/10.21608/pserj.2019.13387.1002
} 


\title{
PORT-SAID ENGINEERING RESEARCH JOURNAL
}

\author{
Faculty of Engineering - Port Said University \\ Volume 23 No. 2 September $2019 \quad$ pp: 34:45
}

\section{LITERATURE REVIEW}

Many researchers studied the phenomenon of pounding between the adjacent structures and the impact and danger of their occurrence on the behavior of the structure.

Hytham Elwardany et al. (5) Studied the effect of the infill panels on the collision between several adjacent buildings during the earthquake. The study showed that the infill panels have a significant impact on the behavior of the structure and play an effective role in reducing the displacement in some cases. Filling all panels of the bare frames with masonry increases the stiffness and no pounding has been observed. Muhammad Noman et al. (6) Studied the effect of collisions between buildings of different height. The study was carried out by using SAP software and using pushover analysis and in-elastic time history analysis method for these buildings. The study aims to identify the minimum distance between the medium-rise buildings in Pakistan and the effect of collisions on the displacement and the shear force. The study showed that adjacent buildings without a separation distance result in additional shear force. The study also showed that a separation distance greater than 6 inch does not cause a collision and that a 3 inch distance was sufficient for the buildings whose height is up to 3 stories. The study discussed several ways of preventing and reducing the pounding, such as the ways of connecting the buildings by connecting the two columns are expected to the collision and this has reduced the displacement of the attached building. Arpitha k and Umadevi R (7) studied the impact of collisions by model two adjacent structures in different cases and different height on ETABS program. The study shows that for all the studied cases, there is impact force generated between the two adjacent structures due to lack of gap distance. The higher buildings suffer more in terms of displacement and deformation resulting from the collision. M.ghandila et al. (8) studied the impact of collisions on torsionally eccentricity steel frame and its effects on displacement, story drift and shear force. The study show that the values of the story drift of the upper storey of the higher building have greater value compared to other buildings. The shear force of the last storey of the short building has great value compared to other storey as well as the upper floors of the tall building has great value of the shear force.
Many researchers have studied different ways to reduce and mitigation technique:

Robert Jankowski et al. (9) made a laboratory experiment to clarify the role of polymer elements between buildings to reduce effect of collision. He modeled three steel towers on a shaking table to simulate the earthquake. The results of the experiment showed that the polymer elements have an effective role in preventing damage caused by the collision and has an effective role in improving structural properties as it reduces vibration during earthquake.

Shehata E. Abdel Raheem (10) studied the impact of collision on global response of a structure and use rubber shock absorber device as mitigation technique. The Results showed that pounding can amplify the global response of participating structural systems and causing increase in the values of acceleration and shear at various story levels. The use of the rubber shock was effective in reducing the impact force between adjacent structures and thus the acceleration values also decreased. The study also showed that the rubber pad size affects the impact force, relative displacement and acceleration responses at expansion joint where responses are significantly decreased with the increase of rubber sock absorbing device size up to half gap size.

Nasser Zaki et al. (11) studied the impact of pounding and ways to mitigation effect of pounding between adjacent buildings by using localized interconnections between different levels of adjacent building. The results showed that Linking of adjacent buildings at Last storey of short building has an effective role in reducing and preventing collisions. The connection of buildings with different level height reduces pounding but at the same time increases the displacement of the short building and increases storey shear above the level of the last story of the shortest building.

\section{NUMERICAL MODELING AND ANALYSIS}

\subsection{Building description}

The building consists of multi-storey reinforced concrete frame building. The floor plans (typical) are shown in Figure 1. The building consists of three bays in each direction, the width of the bay is 5 meters and the height of the first storey is $4 \mathrm{~m}$ and the other 3 meters.

Three buildings were discussed, 10 floors, 6 floors and 4 floors, were modeled on the ETABS (as shown in Figure 5).The structural system consists of moment frame 
systems. The buildings were designed according to EC.8 (EN 1998) (4). The structure will be designed for ductility class DCM and framing type DC medium.

\begin{tabular}{|c|c|c|c|}
\hline $\begin{array}{l}\text { Load } \\
\text { name }\end{array}$ & $\begin{array}{l}\text { load } \\
\text { type }\end{array}$ & details & value \\
\hline \multirow{3}{*}{ dead } & \multirow{3}{*}{$\begin{array}{l}\text { Dead } \\
\text { Load }\end{array}$} & $\begin{array}{c}\text { Self-Weight of Structural } \\
\text { Members Calculate } \\
\text { automatically using Self } \\
\text { Weight Multiplier in } \\
\text { ETABS } \\
\end{array}$ & - \\
\hline & & $\begin{array}{l}\text { Uniform Load on Slabs: } \\
\text { (Finishing + Partition } \\
\text { Load) }\end{array}$ & $2 \mathrm{kN} / \mathrm{m} 2$ \\
\hline & & $\begin{array}{l}\text { Uniform Load on Beams: } \\
\text { (Wall Load) }\end{array}$ & $0.9 \mathrm{kN} / \mathrm{m} 2$ \\
\hline Live & $\begin{array}{c}\text { Reduc } \\
\text { ible } \\
\text { Live } \\
\text { Load }\end{array}$ & $\begin{array}{c}\text { live load (variable, } \\
\text { imposed load) } \\
\text { which is reduced with } \\
\text { factor } \psi_{2 \mathrm{i}}=0.3 \text { (EN } \\
\text { 1990/Table A.1.1, office } \\
\text { building), }\end{array}$ & $2 \mathrm{kN} / \mathrm{m} 2$ \\
\hline
\end{tabular}

Figure 1 Structural layout of the building.

The slab thick is $0.15 \mathrm{~m}$ thick and the Column and beam sections are designed in ETABS by auto select list which is a list of previously defined concrete sections.

\subsection{Loads affecting the structures}

The loads that affect the building which have been studied and taken into consideration for the design of the structure are divided into two parts; firstly, vertical loads as shown in the table 1

Table 1 The values of vertical loads

Secondly, seismic action which can be exposed to the structure and these loads are characterized by changing over time (time-varying load). The seismic analysis can be linear analysis or non-linear analysis.

The linear analysis can be static (lateral force method) or dynamic (modal response spectrum).

The non-linear analysis can be static (pushover analysis) or dynamic (inelastic time history analysis).
In this study response spectrum method was used to compare and verify the safety of the design of frame section without consideration pounding effect.

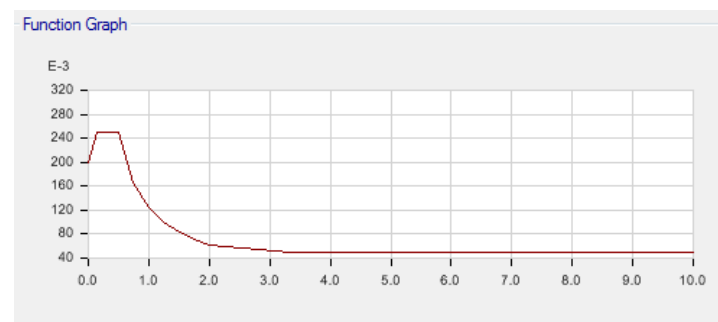

Figure 2 Structural layout of the structure.

Table 2 Response spectrum parameters

\begin{tabular}{|c|c|}
\hline parameter & value \\
\hline DAMPING & .05 \\
\hline Ground type & $\mathrm{B}$ \\
\hline Spectrum type & 1 \\
\hline Soil factor, $\mathrm{S}$ & 1.2 \\
\hline Ground acceleration, $\mathrm{ag} / \mathrm{g}$ & .25 \\
\hline Spectrum period, Tb & .15 \\
\hline Spectrum period, $\mathrm{Tc}$ & .5 \\
\hline Spectrum period, $\mathrm{Td}$ & 2 \\
\hline Lower bound factor, beta & .20 \\
\hline Behavior factor, $\mathrm{q}$ & 3 \\
\hline
\end{tabular}

Non-linear direct integration time history analysis was used as a method of analysis taking into account the effect pounding. A two-dimensional finite element model was used to model the structure.

El Centro Earthquake time history function was selected as shown in figure 3 and response spectra for El Centro earthquake and time period of structures as shown in figure 4

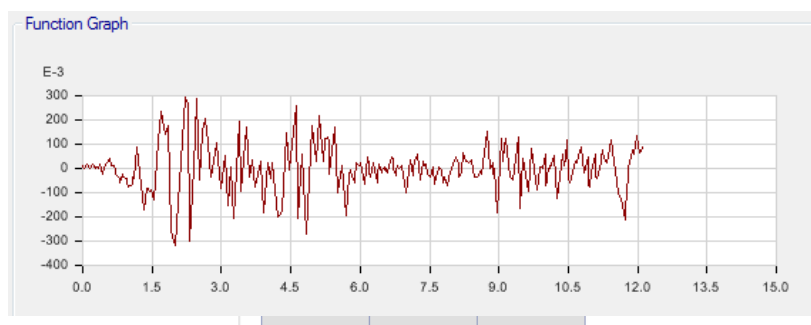

Figure 3 Structural layout of the structure.

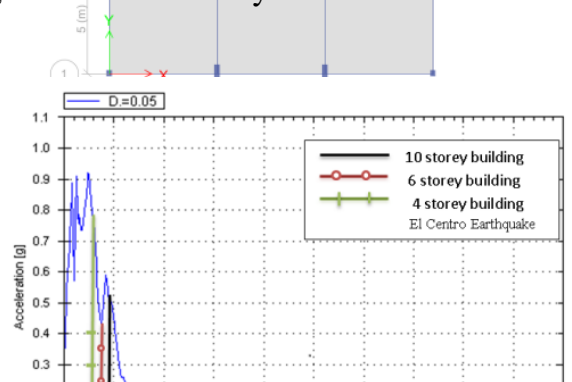


Figure 4 response spectra for El Centro earthquake
R1 and R2 the equivalent spheres of colliding bodies

$R_{i}=\sqrt[3]{\frac{3 m_{i}}{4 \pi \rho}}$

Where $m_{i}$ is colliding mass and $\rho$ is the density of concrete.

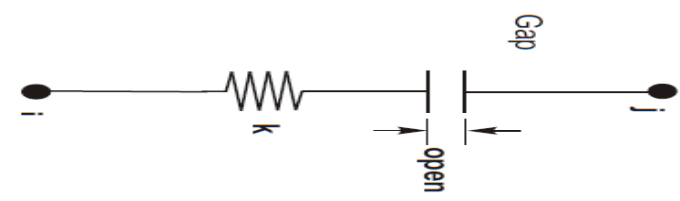

Fig 5 Gap element model.

\subsection{Gap element tool}

The ETABS program provides the ability to represent the connection between the two adjacent structures during the collision by gap elements (as shown in figure 5). Gap element is a tool used to simulate pounding between two buildings during an earthquake and occurs when the displacement of each building is larger than the gap distance.

The properties of the gap element are determined by csi reference manual (14). Gap element tool consists of six degree of freedom each degree of freedom is independent.

Gap element is a non-tension element (transmit compression force only).

The nonlinear force-deformation relationship is given by:

$$
f= \begin{cases}\mathbf{k}(d+\text { open }) & \text { if } d+\text { open }<0 \\ 0 & \text { otherwise }\end{cases}
$$

Where $\mathrm{k}$ is the spring constant, $\mathrm{d}$ is the relative deformation across the spring and open is initial gap opening, which must be zero or positive.

Gap element stiffness proportional to the axial stiffness of the colliding structure $(\mathrm{EA}=\mathrm{L})$ or can defined by Hertz model (12) where $\mathrm{K}$ is the impact stiffness determined by the geometry of the colliding bodies and can be written as:

$\mathrm{k}=\frac{4}{3 \pi(\mathrm{h} 1+\mathrm{h} 2)}\left(\frac{\mathrm{R} 1 \mathrm{R} 2}{\mathrm{R} 1+\mathrm{R} 2}\right)^{1 / 2}$

Where $\mathrm{h} 1, \mathrm{~h} 2$ are material parameters defined as:

$h_{i}=\frac{1-v_{i}}{\pi E_{i}} ; \quad \mathrm{i}=1 ; 2$

Where $v_{i}$ and $E_{i}$ are the Poisson's ratio and modulus of elasticity.

\subsection{Stage of analysis}

Stage 1: Design of the structure under the effect of gravity and earthquake load (response spectrum method)

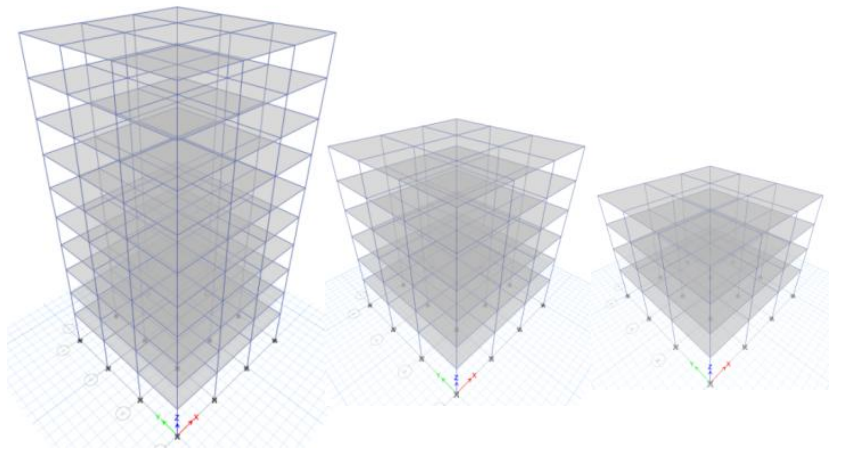

a) ten story building b) six story building c) four story building

Figure 6 Isometric views of examples building.

Stage 2: Analysis of the structure under the impact of gravity and earthquake load (inelastic time history analysis)
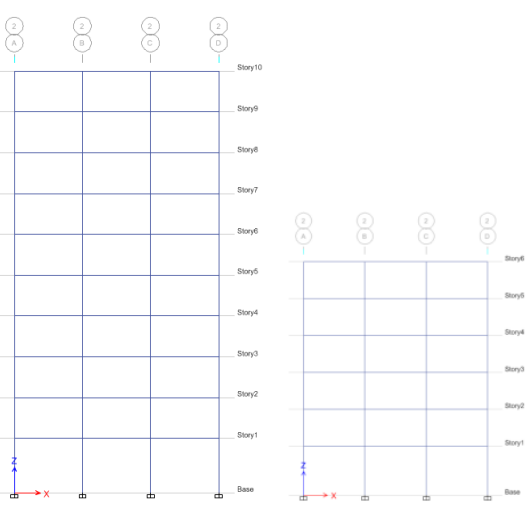
a) ten story building b) six story building c) four story building

Figure 7 Two dimensional finite element models. Stage 3 pounding between adjacent buildings Several cases will be studied to clarify effect of pounding between buildings.

Table 3 Case studies

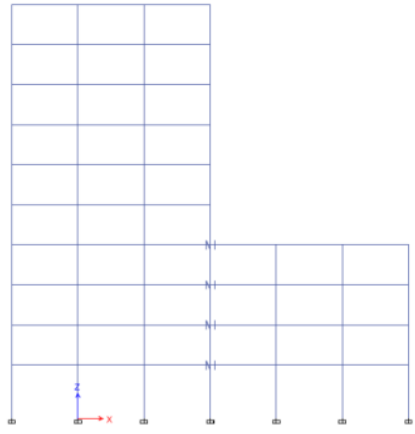

Figure 8 Two adjacent buildings (10-4).

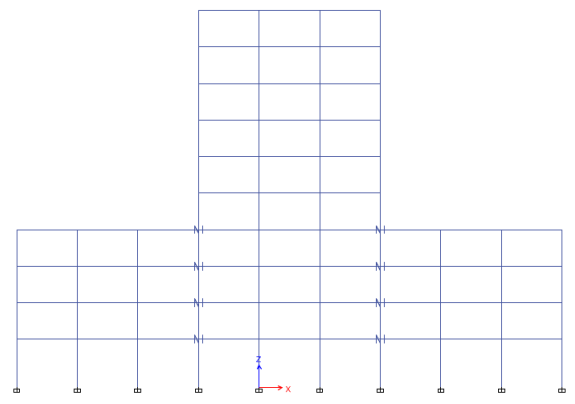

Figure 9 Three adjacent buildings (4-10-4).

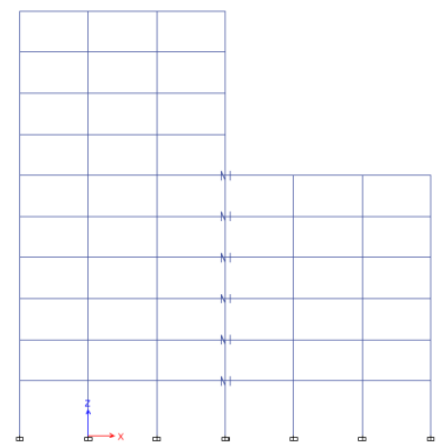

Figure 10 Two adjacent buildings (10-6).

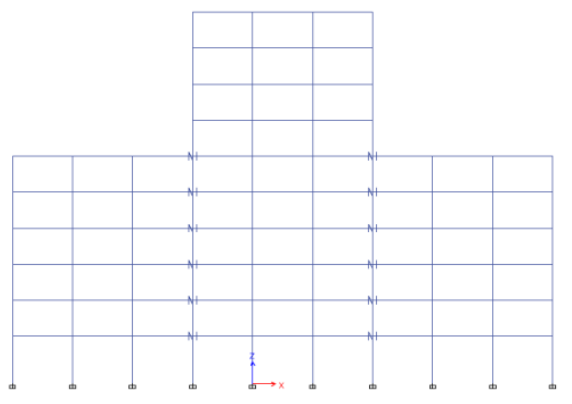

Figure 11 Three adjacent buildings (6-10-6).

\section{RESULTS AND DISCUSSIONS}

Table 4 Result of design section

\begin{tabular}{|c|c|c|}
\hline building & columns & beams \\
\hline $\begin{array}{l}10 \text { storey } \\
\text { building }\end{array}$ & $30 * 150$ & $20 * 50$ \\
\hline $\begin{array}{c}6 \text { storey } \\
\text { building }\end{array}$ & $\begin{array}{c}\text { Outer col } 25 * 60 \\
\text { Middle col } \\
30 * 80\end{array}$ & $20 * 50$ \\
\hline $\begin{array}{l}4 \text { storey } \\
\text { building }\end{array}$ & $25 * 60$ & $20 * 50$ \\
\hline
\end{tabular}

\subsection{Case 1: (10-4) storey building}

\section{(Displacement results)}

In case of 10-storey building, there are increases in the results of the displacement in the direction of the adjacent building. The displacement values have increased in upper storey from the fifth storey to the tenth storey. In the other direction, the results of the maximum storey displacement decreased for all storey.

In case of 4-storey building, the results of the maximum storey displacement have changed better in all cases compared to the case of building without pounding. The displacement in the direction of the 10-storey building was significantly lower than the other direction. This is because the ten-storey building restricts the movement of the fourstory building in this direction.

\begin{tabular}{|c|c|c|c|}
\hline \multirow{2}{*}{$\begin{array}{c}\text { (10-4) storey } \\
\text { buildings }\end{array}$} & Case 1 & $\begin{array}{c}\text { Two adjacent } \\
\text { buildings }\end{array}$ & Gap $(1 \mathrm{~cm}, 2 \mathrm{~cm})$ \\
\cline { 3 - 4 } & $\begin{array}{c}\text { three adjacent } \\
\text { buildings }\end{array}$ & Gap $(1 \mathrm{~cm}, 2 \mathrm{~cm})$ \\
\hline \multirow{2}{*}{$\begin{array}{c}\text { (10-6) storey } \\
\text { buildings }\end{array}$} & Case 2 & $\begin{array}{c}\text { Two adjacent } \\
\text { buildings }\end{array}$ & Gap $(1 \mathrm{~cm}, 2 \mathrm{~cm})$ \\
\cline { 3 - 4 } & $\begin{array}{c}\text { three adjacent } \\
\text { buildings }\end{array}$ & Gap $(1 \mathrm{~cm}, 2 \mathrm{~cm})$ \\
\hline
\end{tabular}




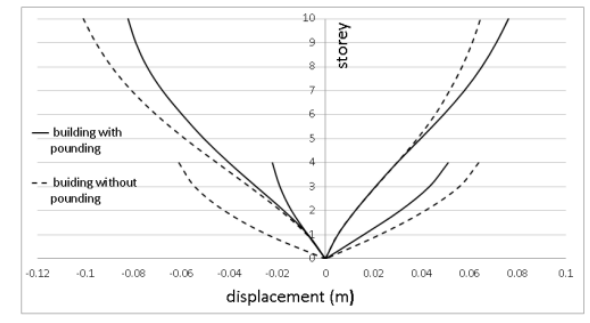

a) (10-4) adjacent buildings with gap $1 \mathrm{~cm}$.

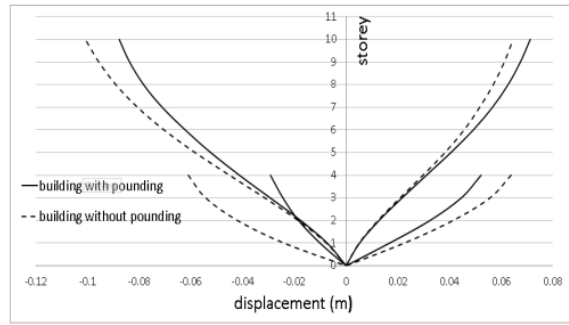

b) (10-4) adjacent buildings with gap $2 \mathrm{~cm}$.

Figure 12 Maximum storey displacement of (10-4) adjacent buildings.

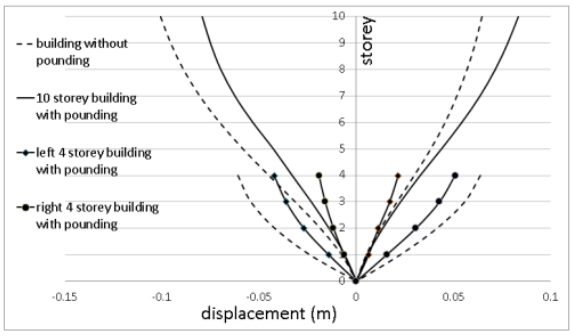

a) (10-4) adjacent building with gap $1 \mathrm{~cm}$.

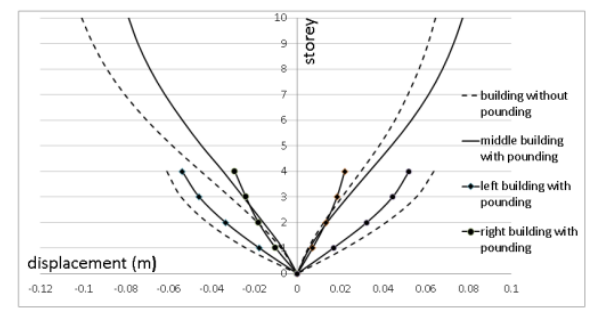

b) (10-4) adjacent buildings with gap $2 \mathrm{~cm}$.

Figure 13 Maximum storey displacement of
(10-4) adjacent buildings.

\section{Case 1: (10-4) storey building (The results of max storey shear force)}

In case of 10-storey building, there is an increase in the max storey shear force as a result of the pounding. There is a significant increase of the shear force results from the fifth storey (directly above the collision level) until the last storey. The results increased by $76 \%$ at the level of the last storey and up to $73 \%$ at the level of the fifth storey in the case of building in series with gap $2 \mathrm{~cm}$.

The max shear force at the level of the fifth storey is a critical because the increase rate is significant and effective compared to normal case without pounding .This increase has a significant impact on the safety of the structure.

Also, the rate of increase in the results of the shear force in the last storey is big and effective and columns size are usually minimized in the last storey so these results should be considered.

In case of four-storey building, The first and last storey are the most affected where The shear force increased in the fourth storey by $70 \%$ in the case of three adjacent buildings with gap $1 \mathrm{~cm}$ and increased by $60 \%$ in the ground storey in the case of two adjacent buildings with a gap $2 \mathrm{~cm}$.

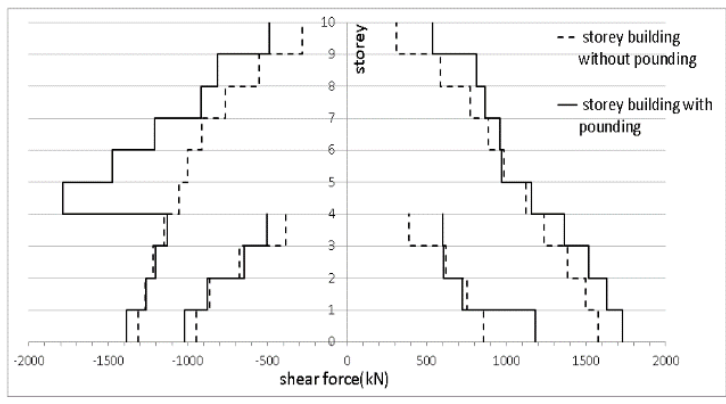

a) Maximum storey shear force with gap $1 \mathrm{~cm}$.

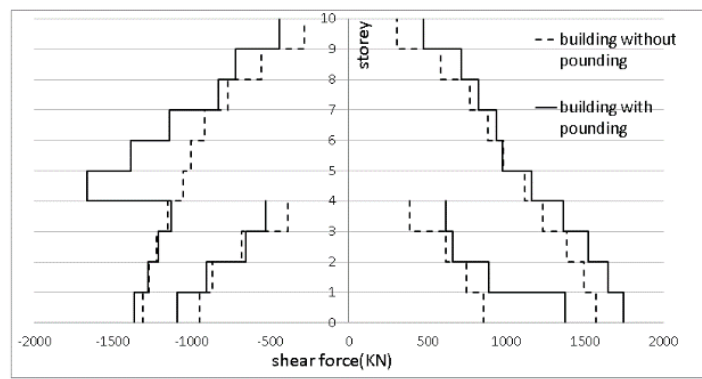

b) Maximum storey shear force with gap $2 \mathrm{~cm}$.

Figure 14 maximum storey shear force of (10-4) adjacent buildings.

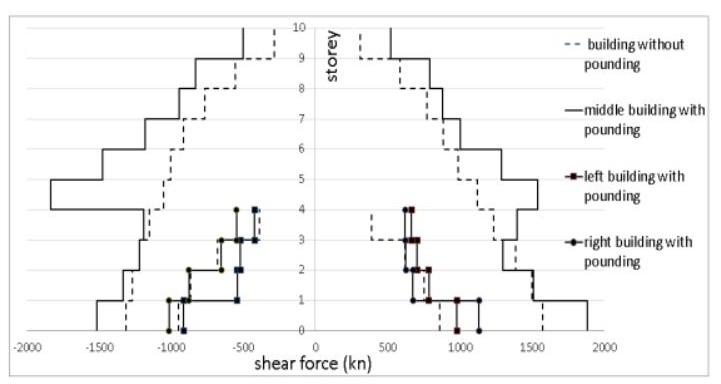


a) Maximum storey shear force with gap $1 \mathrm{~cm}$.

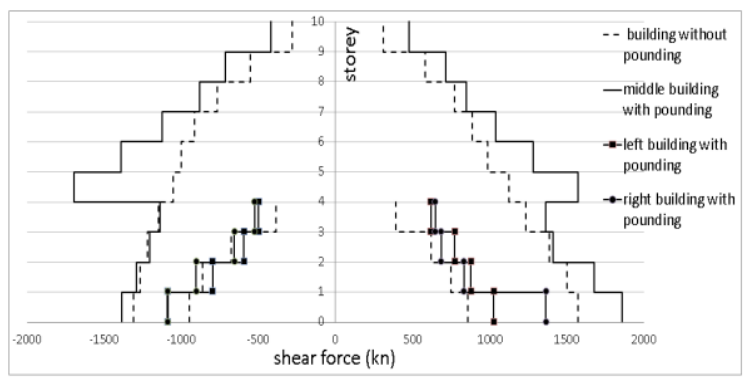

b) Maximum storey shforce with gap $2 \mathrm{~cm}$.

Figure 15 maximum storey shear force of (4-10-4) adjacent buildings.

\section{The results of max storey drift:}

In case of ten-storey building, there is an increase in the value of the maximum storey drift in the direction of the adjacent building in the case of two adjacent buildings where the increase is from the fifth storey (directly above the level of collision) until the tenth storey. The largest value of storey drift was in the tenth storey where it reached .00258 in the case of two adjacent buildings with a gap distance $1 \mathrm{~cm}$ with an increase rate of $67 \%$ compared to the building without pounding.

The maximum storey drift in the other direction in case of pounding decreased compared to the normal situation without pounding.

In the case of three adjacent buildings there is an increase in storey drift in both directions and the greatest value of the storey drift was in the case of gap distance $1 \mathrm{~cm}$ and reached 0.00252 with an increase rate up to $63 \%$ compared to the normal situation without pounding.

In case of four-storey building, the value of the maximum storey drift decreased in the most cases, except in the case of building in series with gap $2 \mathrm{~cm}$, where there is a slight increase in the value of the maximum storey drift on the last storey.

The value of the maximum storey drift on the level of the last storey in the case of building in series with gap $2 \mathrm{~cm}$ was 0.0032 with a percentage increase of $27 \%$ compared to the normal situation without pounding.

So the 10-storey building is the most affected and suffering from the pounding.

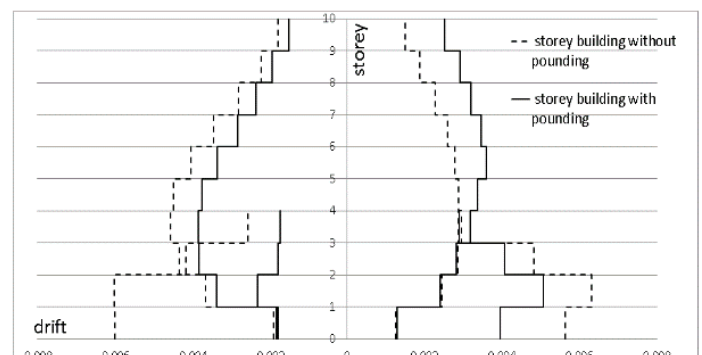

a) Maximum storey shear force with gap $1 \mathrm{~cm}$.

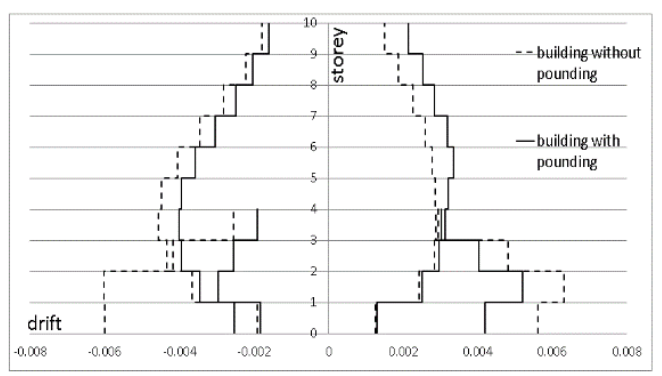

b) Maximum storey shear force with gap $2 \mathrm{~cm}$.

Figure 16 maximum storey drift of (10-4) adjacent buildings.

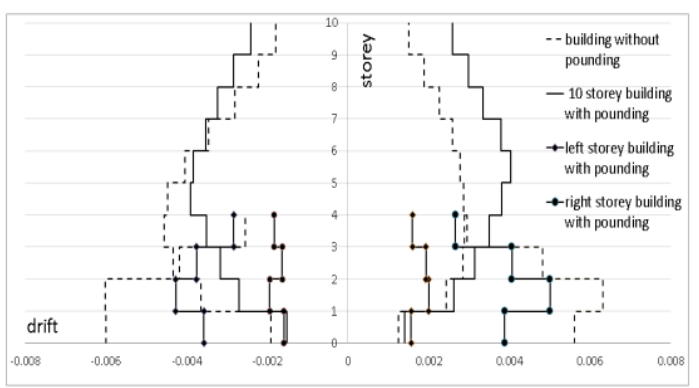

a) Maximum storey shear force with gap $1 \mathrm{~cm}$.

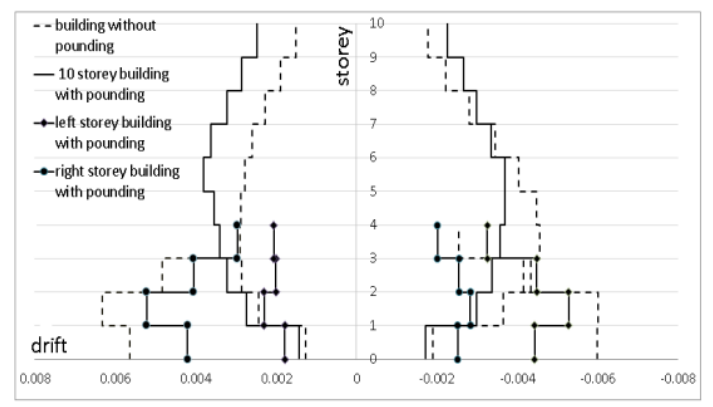

b) Maximum storey shear force with gap $2 \mathrm{~cm}$.

Figure 17 Maximum storey drift of (4-10-4) adjacent buildings.

\subsection{Case 2: (10-6) storey building (The results of max storey displacement)}

In case of 10-storey building, In the case of two adjacent building the results of the displacement decreased in the direction of the adjacent structure and increased in the other direction. The case of adjacent buildings with gap distance $1 \mathrm{~cm}$ is more critical than the case of adjacent 
buildings with gap $2 \mathrm{~cm}$, where the max story displacement in case of gap distance $1 \mathrm{~cm}$ increased by $18 \%$ in the free direction and a decreased by $78 \%$ in the direction of the adjacent building.

In the case of building in series, the results of the top storey of the 10-storey building are almost identical with the results of the same building without pounding, but there is a slight increase in the lower storey in the direction of the adjacent building.

The maximum value of displacement in the case of no pounding was $-0.1 \mathrm{~m}$ and the maximum value in the case of a pounding $0.12 \mathrm{~m}$.

Therefore, the pounding negatively affected the results of the displacement.

In case of 6-storey building, the results show that the sixstorey building is the most affected compared to the 10storey building. The results of the displacement in the direction of the left building was significantly decreased by $68 \%$ in the case of building in series with gap $1 \mathrm{~cm}$ and $69 \%$ in the case of two adjacent buildings and with gap 1

$\mathrm{cm}$.

For the other direction, there is a large increase in the values of the max displacements in case of three adjacent buildings and in case of two adjacent buildings with gap 1 $\mathrm{cm}$ where the displacement increased by $49 \%$ and $50 \%$, respectively. The max value for displacement in the case of no pounding was $0.068 \mathrm{~m}$ and the max value in the case of pounding was $0.082 \mathrm{~m}$ (in the case of building in series with gap $1 \mathrm{~cm}$ ). The pounding negatively affected the results of the building of the six-storey building.

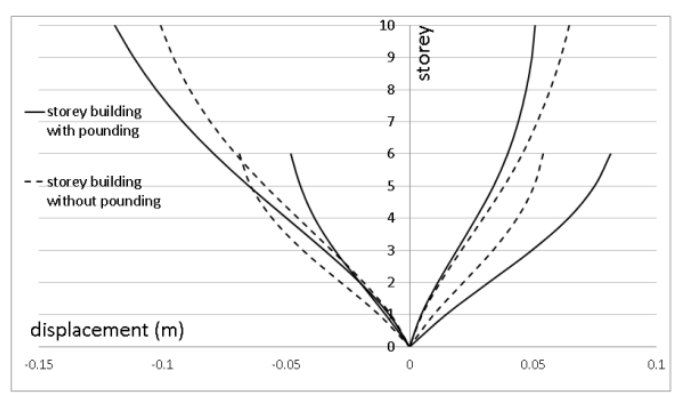

a) Maximum storey displacement with gap $1 \mathrm{~cm}$.

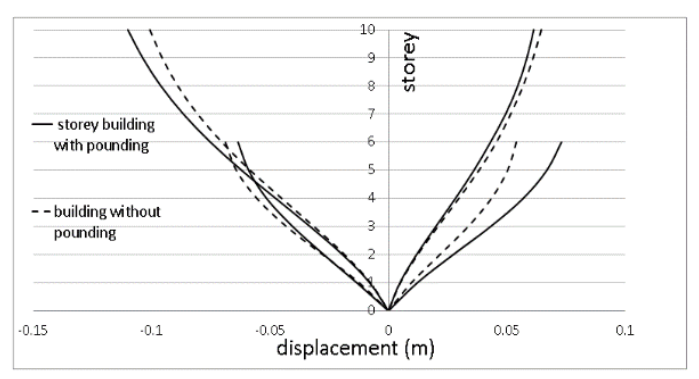

b) Maximum storey displacement with gap $2 \mathrm{~cm}$. Figure 18 Maximum storey displacement of (10-6) adjacent buildings.

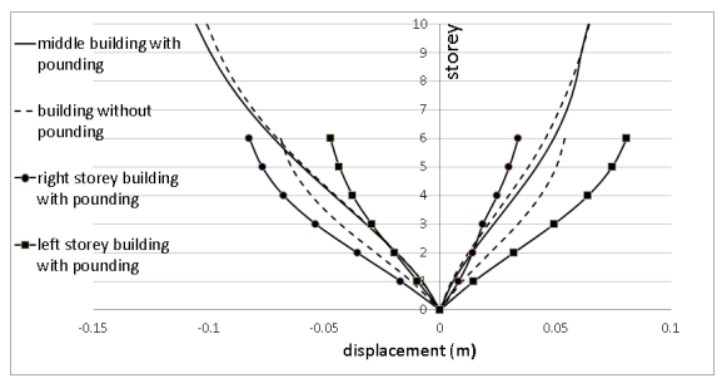

a) Maximum storey displacement with gap $1 \mathrm{~cm}$.

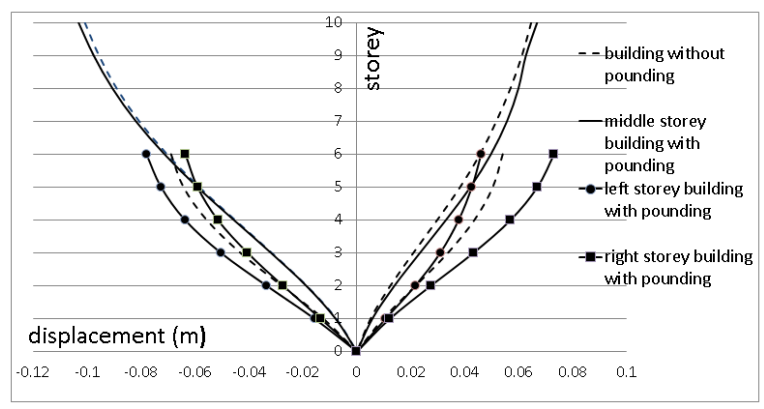

b) Maximum storey displacement with gap $2 \mathrm{~cm}$.

Figure 19 Maximum storey displacement of (6-10-6) adjacent buildings.

\section{Case 2: (10-6) storey building (max storey shear force)}

In case of 10-storey building, there is an increase in the results of the shear force from the seventh storey (directly above the collision level) until the last storey.

The max increase rate occurred on the last storey where the storey shear force increased by $54 \%$ in the case of two adjacent buildings with a gap distance $1 \mathrm{~cm}$. The storey shear force in the level of the seventh storey increased by $46 \%$ in the case of building in series with gap $1 \mathrm{~cm}$.

In case of 6-storey building, there is an increase at all storey and where the storey shear force increased $163 \%$ at the level of the last storey in the case of three adjacent building

This increase is very large and very effective. It can be said that the six storey building is the one who suffers more and affected by pounding.

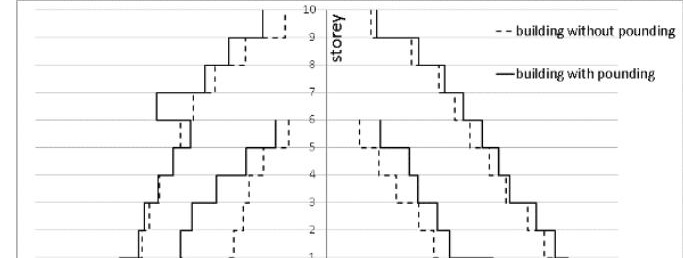


a) Maximum storey shear force with gap $1 \mathrm{~cm}$.

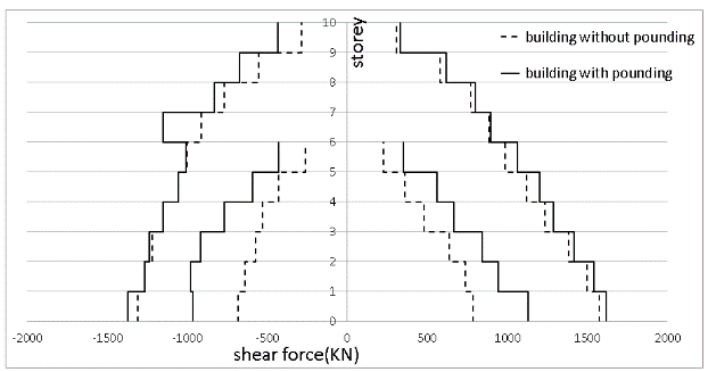

a) Maximum storey shear force with gap $1 \mathrm{~cm}$.

Figure 20 Maximum storey shear force of (10-6) adjacent buildings.

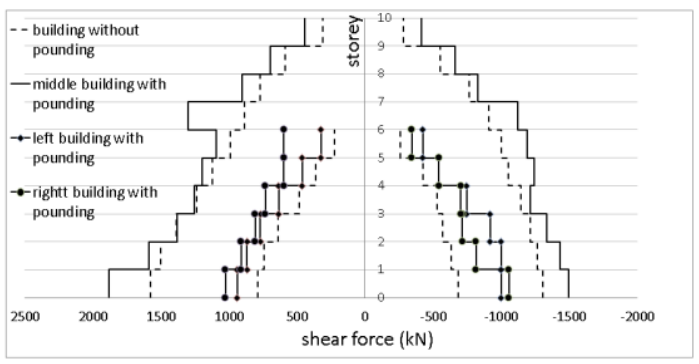

a) Maximum storey shear force with gap $1 \mathrm{~cm}$.

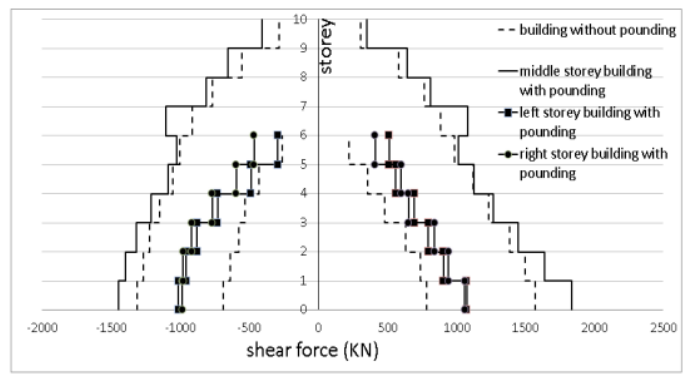

b) Maximum storey shear force with gap $1 \mathrm{~cm}$.

Figure 21 Maximum storey shear force of (6-10-6) adjacent buildings.

\section{Case 2: (10-6) storey building}

\section{(The results of storey drift)}

In case of ten-storey building, there is an increase in the value of the story drift in the opposite direction of the adjacent building in the case of two adjacent buildings. In the case of three adjacent buildings, there is an increase in all cases from the seventh storey (directly above the collision level) until the tenth storey.
The max increase was in the level of the tenth storey in the case of two adjacent buildings with a gap of $1 \mathrm{~cm}$, where it reached 0.00259 in the case of a pounding and the value of the maximum storey drift in the case of no pounding was $0.0015 \mathrm{~m}$, which increased by $45 \%$.

In the direction of the adjacent building, the results were almost unchanged except in the case of two adjacent buildings with a distance of $1 \mathrm{~cm}$.

In case of six-storey building, the value of the drift was significantly increased in the opposite direction of the adjacent building. The largest increase was in the case of two adjacent buildings. The value of the max drift reached .0023 in case of pounding and .0012 in case of no pounding where the result increased by $89 \%$.

In the other direction the value of the drift decreased in most cases, except in the case of three adjacent buildings with a distance of $1 \mathrm{~cm}$.

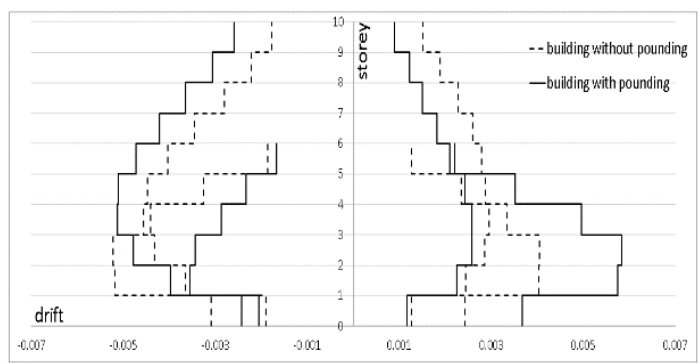

a) Maximum storey drift with gap $1 \mathrm{~cm}$.

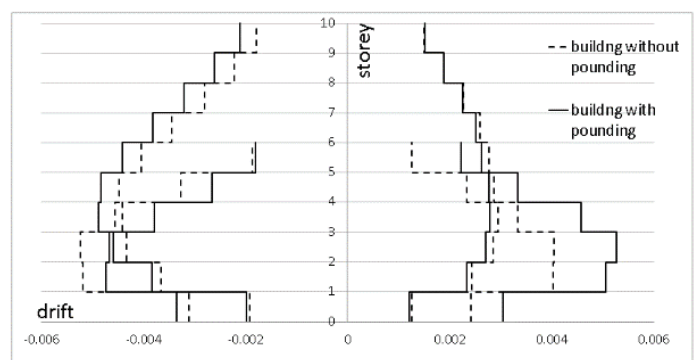

b) Maximum storey drift with gap $2 \mathrm{~cm}$.

Figure 22 Maximum storey drift of (10-6) adjacent buildings.

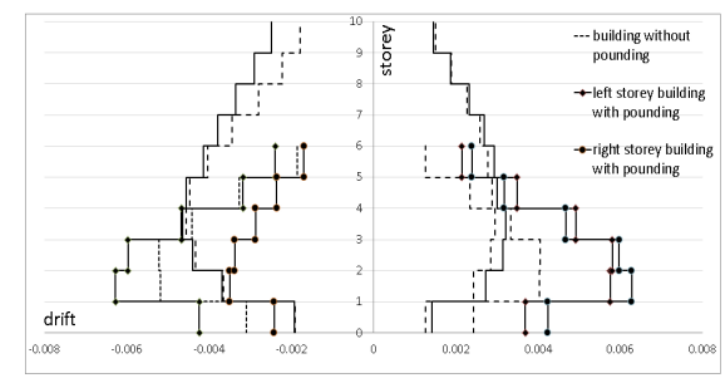


a) Maximum storey drift with gap $1 \mathrm{~cm}$.

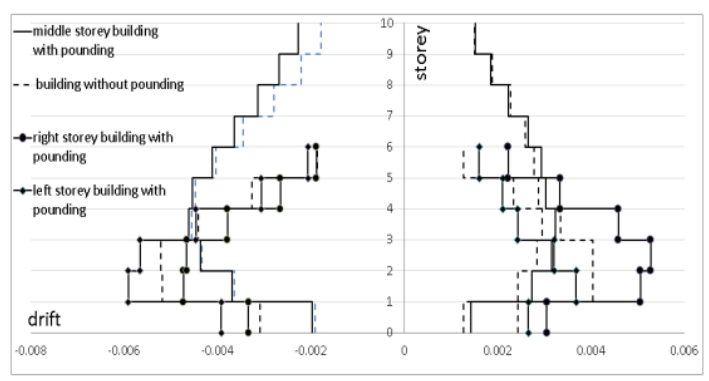

b) Maximum storey drift with gap $2 \mathrm{~cm}$.

Figure 23 Maximum storey drift of (6-10-6) adjacent buildings.

\section{CONCLUSION}

Conclusion of some important points can be summarized as follows:

1- The higher the height of the floor the greater the impact force and number of collisions generated to reach the largest value at the level of the last storey of the shortest building.

2 - The first floor did not have a collision in all cases.

3- Pounding increase max story shear force for all cases:

In case of the ten storey building, there is an increase of storey shear force above the level of the adjacent short building where we find the largest increase of storey shear force in the level of storey above the next short building.

The maximum increase of the results occurred in the case of (10-4) adjacent buildings due to a large difference in height and mass between the adjacent buildings where the shorter structure works as a barrier to the tall building. The lower part of the ten-story building is constrained by the short building while the upper part moves under the influence of the large unrestricted mass and the result of the earthquake movement Therefore, a large force is generated above this level.

In case of the six storey building, there is an increase in shear force in all storey and in most cases where the biggest increase occurred in the level of the last storey.

In case of the four storey building, there is an increase in shear force in the first and last storey.
4- Pounding increase storey drift in the case of the ten and six storey building while the effect on the four storey building in most cases was positive.

In case of the ten storey building, there is a significant increase in the values of storey drift, especially when there is a large difference in height between the two adjacent buildings such as a case of (10-4) adjacent buildings.

5- The results of the storey displacement show that the pounding decrease the storey displacement for the four storey building in the case of the (10-4) adjacent buildings.

In case of the ten storey building, there is increase of storey displacement in case of (10-4) in the direction of the adjacent building and in case of (10-6) adjacent buildings the pounding increases the storey displacement in the opposite direction of the adjacent buildings.

In case of (6-10-6) adjacent buildings the result of the storey displacement of the ten-storey building was close to normal case without pounding due to its restricted movement by the outer six storey building.

In case of (10-4) adjacent buildings the storey displacement increases in the direction of the adjacent building and in case of (10-6) adjacent buildings the pounding increases the storey displacement in the opposite direction of the adjacent buildings however, in the case of (6-10-6) the result of the storey displacement of the tenstorey building was close to normal case without pounding due to its restricted movement by the outer six storey building.

For 6-storey building, there is a significant increase in displacement due to the impact of the ten-storey building on the movement of the smaller building (six storey building) as a result of the collision.

\section{REFERENCES}

[1] G.L. Cole, R.P. Dhakal, A.J. Carr, D.K. Bull. Case studies of observed pounding damage during the2010 Darfield earthquake. Bulletin of the New Zealand Society for Earthquake Engineering 2011; 43 (4): 382-386.

[2] Kazuhiko Kasai, Bruce F. Maison. Building pounding damage during the 1989 Loma Prieta earthquake. Eng Struct. 1997; 19(3): 195-207.

[3] William C. Stone, Felix Y. Yokel. Engineering Aspects of the September 19, 1985 Mexico. Natl. Bur. Stand. May 1987; SERIES 165:165-215.

[4] Eurocode-Basis of structural design BS EN 1990:2002

[5] Hytham Elwardany, Ayman Seleemah, Robert Jankowski. Seismic pounding behavior of multi-story 
buildings in series considering the effect of infill panels. Eng Struct. 2017; 144: 139-150.

[6] Muhammad Kamal, Muhammad Noman, Bashir Alam, Muhammad Fahad. Effects of pounding on adjacent buildings of varying heights during earthquake in Pakistan. Cogent Engineering. 2016; 3(1)

[7] Arpitha K, Umadevi R. Effect of seismic pounding between reinforced concrete buildings. NTERNATIONAL JOURNAL OF LATEST TRENDS IN ENGINEERING ANDTECHNOLOGY. 2016; 7 (2): 576-583.

[8] M. Ghandila .Seismic impact between adjacent torsionally coupled buildings. Soil Dynamics and Earthquake Engineering. 2019; 117: 81-95.

[9] Robert Jankowski (2017) Preventing of earthquakeinduced pounding between steel structures by using polymer elements - experimental study. X International Conference on Structural Dynamics, EURODYN 2017

[10] Shehata E, Abdel Raheemc. Mitigation measures for earthquake induced pounding effects on seismic performance of adjacent buildings. Bulletin of Earthquake engineering. 2014.

[11] Nasser Zaki, Mohamed abdel-mooty. Pounding Mitigation in Buildings using Localized Interconnections. Conference: Advances in Structural Analysis and Mechanics (ASEM17).2017.

[12] Susendar Muthukumar, Reginald DesRoches. A Hertz contact model with non-linear dampingfor pounding simulation: Earthquake Engng Struct . 2006; 35:811-828. [13] Robert Jankowski, Sayed Mahmoud. EarthquakeInduced Structural Pounding. GeoPlanet: Earth and Planetary Sciences (C) Springer International Publishing Switzerland 2015.

[14] Computers \& Structures. Automated Lateral Loads Manual for ETABS $®$ •

[15] Computers \& Structures. CSI Analysis Reference Manual for SAP2000®, ETABS®, SAFE® and CSiBridge

[16] Computers \& Structures. CSI Analysis Reference Manual for Concrete Frame Design Manual Eurocode 22004 with Eurocode 8-2004For ETABS® 


\section{تحليل اصطام بين مبنيين متجاورين أثناء حدوث زلزال \\ ملخص البحث}

تعتبر ظاهرة تصادم المنشآت المتجاورة هي واحدة من اخطر الظو اهر التي ممكن ان تحدث الثناء الزلازل الإل والتي

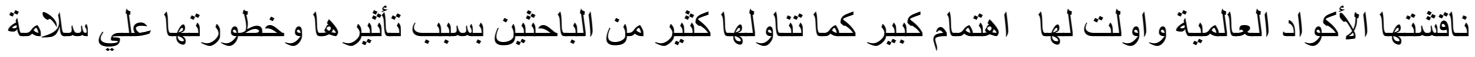

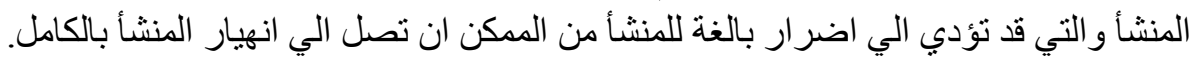

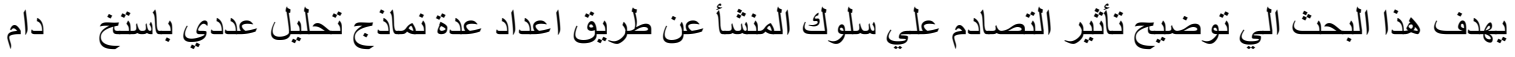
برنامج ETABS للمباني تحت الدر اسة واستخدام عدة طرق للتحليل منها طريقة طيف التجاوب التهاب وطريقة التحليل الديناميكي الزمني.

تم اختيار عدة متغيرات لتوضيح تأثير حدوث التصادم منها فرق الارتفاعات لمباني الهتجاورة وكنلك المسافة الفاصلة

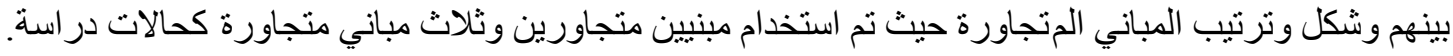
النتائج اثثتت ان ظاهرة التصادم لها تأثير سيء في معظم الحالات حيث عملت علي زيادة الإزاحة وقوي القص عند

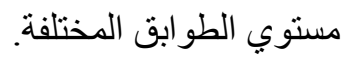

تم مناقثة افضل الطرق لمنع وتقليل حدوث التصادم عن طريق اخ تيار مسافة فاصلة كافية تستو عب حركة المنشأ. اثناء الز لازل بأمان دون حدوث تصادم. 